\title{
PERLINDUNGAN HUKUM TERHADAP ISTRI DAN ANAK HASIL POLIGAMI SIRRI DI LOMBOK
}

\author{
Muhlas \\ Hakim Madya Utama \\ Wakil Ketua Pengadilan Agama Kls. 1 A Pekalongan.
}

\begin{abstract}
Fanaticism on the teachings of Islam in Lombok is very strong, many unregistered marriages and divorce outside their congregation believes that it is legitimate according to religion and the majority of Lombok people's belief, but it does not affect the low protection of wives and children of polygamy sirri. In this paper the author tries to explore the weaknesses of legal protection of wives and children resulting from polygamy sirri in Lombok today By using the approach of social legal risecht, which is used in research based on the paradigm of constructivism the author seeks to find legal issues faced by the wife and child results Polygamy sirri in Lombok. The result is polygamy sirri which is continuously done by people who only rely on fikh doctrine without regard to other legal doctrine (Positive law) it will cause discrimination to woman (wife) and child because do not have base of protection.
\end{abstract}

\begin{abstract}
Abstrak
Fanatisme pada ajaran Islam di Lombok sangat kuat, banyak nikah tidak tercatat dan talak di luar sidang mereka meyakini yang penting hal itu sah menurut agama dan menjadi keyakinan mayoritas masyarakat Lombok, tetapi tidak disadari berdampak pada rendahnya perlindungan kepada istri dan anak hasil poligami sirri. Dalam tulisan ini penulis berusaha menggali kelemahankelemahan perlindungan hukum terhadap istri dan anak hasil poligami sirri di Lombok saat ini Dengan menggunakan pendekatan social legal risecht ${ }^{1}$, yang dipergunakan dalam penelitian berdasarkan paradigma konstruktivisme penulis berupaya mencari masalah -masalah hukum yang dihadapi oleh istri dan anak hasil poligami sirri di Lombok. Hasilnya adalah Poligami sirri yang terus menerus di lakukan oleh masyarakat yang hanya bersandar pada doktrin fikih tanpa mengindahkan doktrin hukum lain ( hukum Positif) justru akan menimbulkan diskriminasi kepada perempuan (istri) dan anak karena tidak memiliki dasar perlindungan.
\end{abstract}

\section{A. Pendahuluan}

Membaca tujuan pembangunan hukum nasional bagi masyarakat Indonesia adalah adanya tujuan sosial defance (perlindungan sosial) dan adanya tujuan sosia/ welfare (kesejahteraan sosial) sebagaimana yang terkandung dalam pembukaan Undang-undang dasar Negara
Republik Indonesia 1945 alenea ke empat;... untuk membentuk suatu pemerintahan Negara Indonesia yang melindungi segenap bangsa Indonesia dan seluruh tumpah darah Indonesia dan untuk memajukan kesejahteraan umum, mencerdaskan kehidupan bangsa dan ikut melaksanakan ketertiban dunia yang berdasarkan

\footnotetext{
Mengutip pendapat Wheeler dan Thomas (dalam Banakar 2005), studi sosio-legal adalah suatu pendekatan alternatif yang menguji studi doktrinal terhadap hukum. Kata 'socio' dalam socio-legal studies merepresentasi keterkaitan antar konteks dimana hukum berada (an interface with a context within which law exists). Itulah sebabnya mengapa ketika seorang peneliti sosio-legal menggunakan teori sosial untuk tujuan analisis, mereka sering tidak sedang bertujuan untuk memberi perhatian pada sosiologi atau ilmu sosial yang lain, melainkan hukum dan studi hukum (Banakar \& Travers 2005). (vide : Kajian Sosio legal Seri Unsur-Unsur PenyusunanBangunan Negara Hukum,2012, oleh Sulistiyowati dkk,yang diterjemahkan oleh Tristam Moelyono, Pustaka Larasati, Denpasar Bali, cetakan pertama,h.3.
} 
kemerdekaan, perdamaian abadi dan keadilan sosial....2.

Secara riil dalam ranah hukum menjadi tugas hakim,yang dituntut kepada pola pikir hakim adalah melakukan pembebasan terhadap pikiranpikiran tradisional-konvensional,manakala itu menghambat arus pemikiran yang lebih benar. Inilah metoda hukum progresif yaitu membuat hukum selalu terbuka, dinamis dan mengalir. ${ }^{3}$ Akan tetapi jangan sampai berlebihan sikap hakim untuk menciptakan nilai progresif, sehingga melanggar etika dan norma. Yang paling utama agar hakim tidak memutuskan penilaian yang menyimpang dari penilaian yang terdapat kesepakatan dalam masyarakat. ${ }^{4}$

John Austin menyatakan bahwa hukum semata-mata hanya sebagai perintah penguasa (Austin's Broad approach to law was to regard it as the command of the sovereign) ${ }^{5}$. Austin juga menjabarkan tentang hukum dapat di tegaskan bahwa hukum itu sebagai perintah dari badan pemegang kedaulatan dalam sebuah masyarakat yang bias berupa seseorang ,seperti raja atau ratu, atau sekelompok petugas terpilih seperti badan pembuat hukum. ${ }^{6}$

Pandangan tersebut di atas sejalan dengan pendapat Jerome Frank ${ }^{7}$, hukum itu kumpulan aturan lengkap yang ada sejak zaman dahulu dan tidak dapat diubah kecuali terbatas bagi badan pembuat undang-undang yang telah mengubah undang-undang yang telah ditetapkan. Sehingga hakim hanya "dewa hidup"hukum, mereka dapat dikatakan sebagai "hukum yang

2 Himpunan Peraturan Perundang-undangan Republik Indonesia menurut sitem engelbrecht,2006. PT Ichtiar Baru Van Hoeve.Jakarta.. h.15.

3 Mahfud MD,dkk, 2013, Dekonstruksi dan Gerakan Pemikiran Hukum Progresif, Semarang, Thafa Media, Cetakan pertama, Konsursium Hukum Progresif Universitas Diponegoro,h. ix.

4 W.Van Gerven, 1990, Kebijaksanaan Hakim, Terjemahan Hartini Tranggono, Jakarta,Erlangga , h. 64.

5 George Whitecross Paton, A Text Book Of jurisprudence, Second Edition, Oxford At The Clarendon Press,h. 6.

6 Werner Menski,2012, Perbandingan Hukum Dalam Konteks Global Sistem Eropa,Asia dan Afrika, Terjemahan M.Khozim,Nusamedia,cetakan II,h.208. 7 Jerome Frank,2014,Hukum \& Pemikiran Modern,Terjemahan, Rahmani Astuti dari buku Law and The Modern Mind,cetakan II,2014,Nuansa Cendekia,Bandung,h.74-75. berbicara". Fungsi mereka semata-mata pasif tidak lain mereka mulut yang mengucapkan hukum.

Abdul Latif Guru besar Ilmu Hukum Universitas Muslim Indonesia (UMI) Makasar berpendapat;

Pembentukan hukum yang dinamis, baik dalam arti horizontal maupun vertical tidak mungkin tanpa konstansi dan dinamik relatif dari asas-asas hukum materiil. Adalah asasaasas hukum materiil yang bersifat konstitutif dan regulatif yang mendorong terus proses pembentukan hukum,sedangkan sebaliknya asas-asas ini akan mengembangkan arti yuridis dalam pembentukan hukum yang dinamis. Selalu didalam hal itu harus ada suatu harmonisasi antara konstansi relatif dan dinamik relatif dari pemebentukan-pembentukan hukum. ${ }^{8}$

Hakim dalam mewujudkan harmonisasi antara hukum positif sebagai premis mayor dan kasus yang dihadapi adalah premis minor jangan sampai hakim terpasung oleh kepastian yang hanya mengutamakan hukum secara teks tual dan mengabaikan hukum secara kontekstual demi keadilan. Hal itu dapat disadari karena tidak ada Undang-undang yang sempurna dan mampu berlaku konstan dalam waktu tertentu. ${ }^{9}$

Said Aqil Siradj ${ }^{10}$ mengingatkan bahwa Hakim dalam Mewujudkan Keadilan Ilahiyah bagi Masyarakat harus memiliki karakter :Al-kafaah wat taahhul (proporsional) dan professional dalam bertindak .Al-infitah was shaharah (berfikir terbuka dan open managemen). At- ta"awun alal birri wal ihsan ( bekerja sama dalam menegakkan kewajiban dan kemaslahatan).Al-mas'uliyah (bertanggung jawab).

Mengapa hakim diberikan wewenang sebagai judge made law ${ }^{11}$ ? karena hakim memiliki peran dan wewenang untuk merumuskan hukum dalam

8 Jurnal Hukum dan Peradilan volume 02 nomor 1 Maret 2013. Mahkamah Agung RI Badan Penelitian dan Pengembangan Hukum dan Peradilan.h. 20.

9 Yahya harapap, 2012,Hukum Acara Perdata, Jakarta, Sinar Grafika, h. 825 telah menguraikan dan mensitir pendapat Richard A Wasserstrom,bahwa undang-undang sering kabur, mendua dan juga tidak mampu melihat kasus yang timbul dimasa datang (Statutes are aften vague and ambigous).

10 Disarikan dari Komisi Yudisial, 2013,Proceeding Pelatihan Tematik Ekonomi Syariah bagi Pengadilan Agama. Bandung 13-16 Februari 2013. h.72.

11 Varia Peradilan no.254 tahun ke XXII januari 2007,h.5. 
bahasa yang mudah, jelas, tegas dan bermanfaat dengan menunjukkan mana hukum dalam ranah in the book dan mana hukum dalam ranah in action atau out of the book.

Bagir Manan telah memberikan uraian alasan secara rasional dan yuridis tentang perlunya hakim menafsirkan undang-undang , antara lain ${ }^{12}$ :

1. Tidak pernah ada peristiwa hukum yang tepat dan serupa dengan lukisan undangundang (peraturan perundang-undangan), sedangkan Hakim harus menemukan kesesuaian antara fakta dan hukum.

2. Suatu perbuatan tidak tercakup dalam kata atau kata-kata (ordinary word) yang disebut dalam undang-undang.

3. Tuntutan keadilan. Hakim bukan corong undang-undang, sebagai arbiter hakim wajib menyelesaikan suatu perkara dengan adil.

4. Keterbatasan makna bahasa dibandingkan dengan gejala atau peristiwa yang ada atau terjadi dalam masyarakat.

5. Bahasa dapat diartikan berbeda pada setiap lingkungan masyarakat.

6. Pengaruh perkembangan masyarakat.

7. Tranformasi atau resepsi konsep hukum asing yang dipergunakan dalam praktik hukum ( misal: bidang perjanjian, perbankan dll).

8. Pengaruh berbagai teori baru dibidang hukum ( sociological jurisprudence,feminist legal theory dII).

9. Ketentuan atau bahasa atau kata atau kata-kata dalam undang-undang tidak jelas,bermakna ganda, tidak konsisten.

Tulisan ini bermaksud memberikan sumbang saran dan pemikiran bahwa warga negara Indonesia harus memperoleh hak -hak hukum yang sama, bagi yang belum terjangkau perlu dicarikan solusi hukumnya. Paradigma atau kerangka berfikir ${ }^{13}$ penelitian ini adalah untuk meneliti masyarakat Lombok yang melakukan poligami sirri dengan menggunakan pendekatan social legal risecht ${ }^{14}$, yang dipergunakan dalam

12 Varia peradilan majalah hukum tahun XXIV no. 285 agustus 2009 h. 10.

13 Kamus Besar Bahasa Indonesia, 2008,edisi ke tiga,Pusat Bahasa Departemen Pendidikan Nasional, Jakarta,Balai Pustaka, h.828.

14 Mengutip pendapat Wheeler dan Thomas (dalam penelitian berdasar paradigma konstruktivisme ${ }^{15}$, yaitu penelitian untuk berupaya mencari konsep baru sebagai solusi masalah hukum yang dihadapi oleh istri dan anak hasil poligami sirri di Lombok, karena ada harapan penulis untuk memberi sumbang saran dalam merekonstruksi hukum perlindungan istri dan anak hasil poligami sirri yang sampai sejauh ini masih sulit untuk mendapatkan akses perlindungan hukum dalam bentuk apapun.

Perlu dikaji pula mengapa di masyarakat Lombok masih banyak melakukan pernikahan di bawah tangan atau yang lazim di sebut nikah sirri, maupun melakukan perceraian banyak dilakukan tidak di depan persidangan Pengadilan, apakah karena masyarakat tidak peduli dengan pencatatan secara administratif atau masyarakat hanya menjadi korban pihakpihak yang mengambil keuntungan pribadi. Perolehan data dan fakta dari beberapa keadaan tersebut di atas diharapkan akan memberikan gambaran secara detail,sehingga dapat dengan tepat dicarikan salusi hukum sebagai payung untuk memperoleh hak-hak hukum agar tidak mendapat kesulitan ataupun perlakuan diskriminatif akibat ketentuan normatif yang hanya mengutamakan legal formal. Metode penelitian merupakan suatu cara yang digunakan dalam menjalankan aktifitas penelitian mulai dari mengumpulkan data, mengolah dan melakukan analisanya dengan standar dan prosedur tertentu. ${ }^{16}$

Banakar 2005), studi sosio-legal adalah suatu pendekatan alternatif yang menguji studi doktrinal terhadap hukum. Kata 'socio' dalam socio-legal studies merepresentasi keterkaitan antar konteks dimana hukum berada (an interface with a context within which law exists). Itulah sebabnya mengapa ketika seorang peneliti sosio-legal menggunakan teori sosial untuk tujuan analisis, mereka sering tidak sedang bertujuan untuk memberi perhatian pada sosiologi atau ilmu sosial yang lain, melainkan hukum dan studi hukum (Banakar \& Travers 2005). (vide : Kajian Sosio legal Seri Unsur-Unsur PenyusunanBangunan Negara Hukum,2012, oleh Sulistiyowati dkk,yang diterjemahkan oleh Tristam Moelyono, Pustaka Larasati, Denpasar Bali, cetakan pertama,h.3.

15 Agus Salim (red), 2001, Teori dan Paradigma Penelitian Sosial (dari Denzim Guba\& Penerapanya), Yogyakarta,Tiara Wacana h.38.

16 Suharsimi Arikunto, 2002, Prosedur Penelitian Suatu Pendekatan Praktek, Jakarta,Reneka Cipta, h. 126. 
Ada tiga pendekatan yang ingin penulis lakukan, yaitu melaui pendekatan kasus ( Case Approach), pendekatan undang-undang (statute approach) dengan pendekatan pendekatan konseptual (conceptual approach). Pendekatan tersebut dilakukan dengan memperhatikan teori dan metode pemecahan masalah atau penemuan hukum dengan menggunakan norma dan kaidah hukum . Norma dimaksud adalah norma kompetensi absolut dan kaidah syar'i yang harus sejalan seirama melalui penafsiran, penghalusan atau penyimpangan ketentuan peraturan perundang-undangan agar hukum yang berasal dari ketentuan sya'i dan peraturan perundang-undangan tidak saling bertentangan sehingga masyarakat terayomi dari norma itu sendiri. Cara yang dapat ditempuh adalah dengan memahami berbagai symbolik dibalik peran serta hakim dalam memeriksa dan mengadili suatu perkara dapat melalui pendekatan hermeneutic. ${ }^{17}$

\section{B. Pembahasan}

1. Perlindungan Hukum Terhadap Istri dan Anak Hasil Poligami Sirri di Lombok Belum Efektif.

Keadilan yang dijamin adalah keadilan yang menyangkut hak-hak dasar sebagaimana ditetapkan oleh pasal 28 UUD 1945, antara lain disebutkan setiap orang berhak atas pengakuan,jaminan, perlindungan,dan kepastian hukum yang adil serta perlakuan yang sama di hadapan hukum. Membahas perihal perlindungan kepada masyarakat yang terungkap adalah antara lain perlu perlindungan hukum, keadilan, kesejahteraan, ketentramana, kenyamanan, ketertiban, pengayoman dan lain lain. Khusus terhadap perlindungan istri dan anak dalam poligamsi sirri di Lombok adalah dalam kontek masyarakat khusus yang banyak melakukan poligami sirri, padahal dengan poligamsi sirri terdapat banyak kelemahan dalam penerapan

17 Dalam perspektif ilmu hukum hermeneutic dapat diartikan sebagai ilmu nurmatifl, interpretasi,dan eksplanasi yang merupakan dua sisi dalam hermeneutic memainkan peranan penting,baik dalam penyusunan hukum baru,maupun dalam mengelola bahan-bahan hukum menjadi keputusan hukum guna menghadapi kasus-kasus yang factual. (vide: Johnny Ibrahim,h.111 perlindungan hukum bagi pelaku, penekanan utama dalam poligami sirri adalah ada pada personal masyarakat yang terikat dengan pemberlakuan norma hukum karena hidup dalam suatru negara berdaulat. Keadilan juga merupakan salah satu tujuan setiap agama yang ada di dunia ini ,temasuk agama Islam yang menempatkan keadilan di tempat yang sangat penting dalam kehidupan berbangsa dan bernegara. ${ }^{18}$ Filosof Ulpinus menyatakan bahwa keadilan itu adalah kehendak yang rutin dan tetap untuk memberikan kepada masing-masing bagian (Iustitia est contans et perpetua ius suum euique tribuendi). ${ }^{19}$

Indonesia memiliki Pancasila sebagai lambang negara sekaligus sebagai falsafah negara, berperan pula sebagai dalii-dalil filsafat, maka di dalam Pancasila sebagai filsafat adalah kebenaran yang substansial. Oleh karena itu setiap penjabaran Pancasila secara praktis untuk kehidupan bernegara, harus bertolak dari nilai-nilai substansial Pancasila. ${ }^{20}$ $\mathrm{Hal}$ ini yang seharus Pancasila mampu mempunyai arti yang bersifat substanstif dan regulatif; (substantif karena merupakan faham atau pandangan hidup yang fundamental, sedangkan regulatif karena dalam butir-butir sila nampak nilai operatif dan regulatif).

Islam mengajarkan keharusan taat, sebagaimana termaktup dalam al- Qur'an surat An-Nisa' ayat 59; yang Artinya :Hai orang-orang yang beriman, taatilah Allah dan taatilah Rasul (Nya), dan ulil amri di antara kamu.....

Fakta di Lombok, bentuk perlindungan kepada istri dan anak hasil poligami sirri sulit dijangkau maksimal Hal ini terjadi karena mereka tidak memiliki dasar hukum yang menyatakan mereka terikat oleh perkawinan yang sah, sehingga tidak terdata. ${ }^{21} \mathrm{Hal}$ senada di jelaskan oleh ketua LPSDM ${ }^{22}$ Kabupaten

18 H. Abdul Manan,2007, Reformasi Hukum Islam Di Indonesia ATinjauan dari Aspek Legalisasi dan Yurisprudensi,Loc-Cit,h.111.

19 Ibid, h. 112-113

20 Bahder Johan Nasution, Negara Hukium dan Hak Asasi Manusia, Loc-Cit.h.110.

21 Wawancara dengan sekertaris GOW Kabupaten Lombok, tanggal 30 Mei 2016.

22 Wawancara dengan Ketua LPSDM (Ririn Hayudiani) Kabupaten Lombok tanggal 27 Juni 2016. 
Lombok Timur yang menyatakan keberadaan istri poligami sirri di Lombok cukup banyak dan tidak mendapatkan perlindungan hukum karena tidak memiliki dasar hukum yang dapat dijadikan dasar yang sah, selain itu para istri poligami sirri tidak mendapatkan nafkah baik untuk diri maupun untuk anak-anak.

Berbicara mengenai perceraian di bawah tangan yang berdampak pada kemelut hukum adalah sebagaimana Fenomena TKI yang menceraikan istri dari Luar Negeri melalui Telepon yang disaksikan oleh keluarga atau aparat desa, atau yang lebih ekstrim istri diberi kabar perceraian utusan keluarga suami yang menyatakan istri telah di cerai dari luar negeri, kabar perceraian melalui telepon atau kabar dari keluarga pihak suami tersebut langsung di nilai jatuh talak.

Nasib perempuan tersebut sama dengan penuturan Andika Istujaya ${ }^{23}$ bahwa sekuat data apapun yang dimiliki termasuk akta nikah apa bila suami telah melontarkan kata talak istri sudah tidak ada pilihan kecuali harus pulang ke rumah orang tua. Dan masih banyak lagi fakta-fakta lain yang penjatuhan cerai hanya melalui telepon.

Meskipun begitu kita layak merenungkan uraian dari ulama besar Mekkah Syeh Mahmud Saltut ${ }^{24}$ dalam kitab al-Fatawa: Bahwa pembahasan tentang penjatuhan talak, atau hukum jatuhnya talak hakimlah yang memberi keputusan terkait jatuhnya talak, seorang mufti hendaklah tidak memberikan fatwa yang menghukumi tentang jatuhnya talak, kecuali jika keputusanya itu sesuai dengan keputusan yang telah ditetapkan oleh pemimpin terkait hukum jatuhnya talak. Masih menurut Syeh Mahmud Saltut menyatakan bahwa seseorang yang tinggal terpisah atau berjauhan tidak dapat dijadikan sebagai dasar hukum penjatuhan talak, dan selama seorang suami dalam keadaan sempurna maka ia tetap memiliki tanggung jawab penuh terhadap keluarganya.

23 Wawancara dengan Andika Istu jaya tanggal 13 April 2016.

24 Disarikan dari kitab Mahmud Syaltut, 1966, al- Fatawa (diraasatu limusykilati al-muslim almu'asyirin hayatuhu yaumiah wa al-'aamah), Daarul Qalam,cetakan ke 3,h.310-311.

\section{Kelemahan perlindungan hukum terhadap istri dan anak hasil poligami sirri di Lombok saat ini.}

Secara substansi pengaturan perkawinan sudah disediakan perangkat hukum oleh negara yaitu UU No 1 tahun 1974 tentang perkawinan, PP N0. 9 tahun 1975 tentang peraturan pelaksanaan UU perkawinan, $\mathrm{PP}$ No. 10 tahun 1983 yang telah di ubah dengan PP N0 45 tahun 1990 tentang ijin perkawinan dan perceraian bagi PNS dan KHI. Khusus pencatatan perkawinan sudah diatur dalam pasal 2 ayat (2) UU No 1 tahun 1974 tentang perkawinan dan pasal 5 ayat (1) KHI, akan tetapi masih banyak perkawinan masyarakat di Lombok baik monogami maupun poligami yang tidak tercatat.

Pada saat poligami sirri di suatu tempat sudah membudaya akan banyak menemui kesulitan tentang penerapan perlindungan hukum, akan banyak memakan kurban antara lain istri dan anak-anak karena tidak memiliki dasar hukum atas ikatan perkawinan. Keberadaan istri dan anak dalam perkawinan harus memdapatkan perlindungan yang sama sebagai perlakuan hak asasi manusia yang dilindungi oleh konstitusi. Adapun hak-hak anak adalah sebagaimana di uraikan oleh Abdul Mustaqim: ${ }^{25}$ Hak-hak anak dalam al-qur'an adalah : 1. hak untuk hidup dan mendapatkan pelayanan kesehatan (yang disimbulkan dengan menyusu ibu selama dua tahun) , 2. Hak untuk beragama,3. Hak mendapatkan pendidikan, dan 4. Hak untuk berpendapat.

Pada saat substansi hukum yang diberlakukan di suatu negara sedangkan warga negara tidak mengindahkan , akan terdapat kesenjangan antara kewajiban negara melindungi dan mensejahteraan warga yang taat dengan warga negara yang tidak taat pada aturan yang sudah ditetapkan.

Apakah poligami sirri termasuk pelanggaran hukum ? meskipun poligami sudah membudaya di Lombok, di pandang dari sisi UU, maka poligami sirri adalah melanggar UU No. 1 tahun 1974 tentang perkawinan. Ada dua

25 Abdul Mustaqim (Red),2006,Musawa Jurnal StudiGender Dan Islam, Vol. 4 No. 2 Juli 2006,:Pusat Studi Wanita UIN Sunan Kalijaga Yogyakarta,h.167. 
hal yang dilanggar yaitu menyembunyikan perkawinan dari masyarakat termasuk istri pertama dan kedua sengaja menghindari ketentuan pasal 4 dan 5 UU tersebut. Apa lagi sama sekali tidak tampak peran hukum suami dalam identitas hukum istri poligami sirri , suatu contoh dalam kartu keluarga istri menjadi Kepala Keluarga padalah status kawin, nama suami hanya tampak pada penyebutan akte kelahiran anak. Pemberian akte kelahiran pada ana-anak poligami sirri adalah keadaan dilematik bagi Dinas Kependudukan dan Catatan Sipil, apa bila berpedoman pada ketentuan UU kependudukanana-anak hasil poligami sirri tidak mendapatkan identitas hukum seperti anak-anak dari perkawinan biasa disisi lain apa bila di permudah hanya dengan surat keterangan dari desa tentang telah terjadi pernikahan banyak mengandung kelemahan.

Peran hakim dalam mengukur pendapat sikap dan peran hakim dalam menciptakan hukum khusus terhadap kasus perkembangan hukum tentang poligami sirri di Lombok, penulis mencoba menggali pendapat dari 85 orang hakim pengadilan agama yang tersebar di Propinsi Jawa Tengah, Jawa Timur dan Nusa Tenggara Barat dipergunakan untuk menganalisa permasalahan dari sudut pandang Kewenangan Hakim dalam menciptakan hukum yang hasilnya masih belum banyak yang berfikir untuk memberikan solusi perlindungan kepada istri dan anak hasil poligami sirri.

\section{Perlindungan hukum terhadap Istri dan anak hasil Poligami Sirri di Lombok berbasis nilai keadilan.}

Ahmad Ali mengutip pendapat Lawrence M.Friedman membagi keadilan itu menjadi dua yaitu keadilan prosedural dan keadilan substantif; bahwa prosedur hanya merupakan suatu sarana untuk mencapai suatu tujuan; tujuan tersebut yang merupakan problem kolektif apapun di masyarakat, yang dimaksudkan untuk diserang. Prosedur mengikuti substansi, dan substansi yang memberitahu kita,bidang-bidang prosedur mana yang akan menjadi penting.
Terjadi kekosongan hukum tentang perlindungan hukum kepada istri dan anak hasil poligami sirri yang berbasis nilai keadilan. Peran hakim melalui kreasi putusanya sangat menentukan nasib mereka agar mereka memperoleh perlindungan sebagai warga negara yang dilindungi oleh konstitusi, dengan berlindung pada kemaslahatan , maka dengan menggali teori maqasid alsyariah, maslahah dan progresif seharusnya hakim punya peluang membuat hukum (judge made law) seperti membuat peluang itsbat kontensius sepanjang perkawinan tidak terhalang secara syar'i

Adapun teori hukum yang dapat ditemukan dalam kajian ini setelah mengkaji dari berbagai kasus poligami sirri ternyata banyak mendatangkan kerugian / madlarat bagi istri dan anak-anaknya, akan tetapi mereka adalah warga negara yang secara konstitusi harus dilindungi tanpa ada diskriminasi , yaitu dengan terjaminnya perlindungan : 1 . Agama ( (hifdl al-din) 2. Kehidupan/ Jiwa (al-nafs) 3. Kebutuhan intelektual / akal (al-aql) 4. Keturunan (al-nasl) dan 5. Harta/ kekayaan (al-mal); maka dapat ditemukan Teori hukum dloruri sebagai jawabanya.

Meskipun perangkat hukum tentang perkawinan sudah disediakan oleh negara untuk menjamin warga negaranya, akan tetapi perkawinan masih banyak masyarakat Lombok baik mono gami maupun poligami yang tidak tercatat. Kewajiban pencatatan perkawinan yang di haruskan oleh negara melalui UU perkawinan adalah bukti wujud pertenggungan jawaban Negara kepada warga Negara, tanpa bukti hukum tersebut warga Negara tidak akan memperoleh perlindungan hukum dari Negara. Betapa penting penataan perkawinan melalui undang-undang yang diatur oleh negara, fikih yang merupakan bagian dari hukum Islam adalah pendapat dari hasil ijtihad yang dapat berubah-ubah sesuai kondisi masyarakat dan politik suatu negara; padahal di Indonesia agama sudah sedemikian kuat memperoleh perhatian dari negara dengan di akomodasi melalui penegakan undang-undang sebagai sarana pengayoman masyarakat, maka kondisi 
tersebut mengharuskan undang-undang didahulukan dibanding pendapat fikih.

Secara struktural Pengadilan agama di Lombok sudah banyak melakukan pengesahan pernikahan ( itsbat nikah), sebagai upaya memberikan perlindungan dan legalitas kepada pelaku nikah sirri sepanjang tidak bertentangan dengan hukum syar'i, dan sepanjang tidak menimbulkan madlarat dikemudian hari. Namun dengan jumlah pasangan nikah sirri yang sangat banyak, maka banyak pula mereka yang tidak memiliki legalitas hukum dalam perkawinanya. Poligami sirri yang terus menerus di lakukan oleh masyarakat yang hanya bersandar pada doktrin fikih tanpa mengindahkan doktrin hukum lain ( hukum Positif) justru akan menimbulkan diskriminasi kepada perempuan (istri) dan anak karena tidak memiliki dasar perlindungan.

\section{Kesimpulan dan Saran.}

Perlindungan hukum khusus terhadap istri poligami sirri di Lombok belum ada karena dalam status rumah tangga ( istri poligami sirri tersebut ) rata-rata langsung menjadi Kepala Keluarga ,akan tetapi terhadap anak-anak sudah memperoleh perlindungan hukum berupa kemudahan memperoleh akte kelahiran dari Dinas Catatan Sipil dan Kependudukan Kabupaten , hanya dengan melampirkan surat keterangan menikah orang tuanya dari Desa setempat.

Ulama' memiliki peran paling penting dalam tatanan kehidupan sosial di masyarakat Lombok, sehingga ajaran, pendapat dan perilaku di pedomani oleh masyarakat secara umum. Hukum Islam adalah harga mati di kalangan masyarakat Lombok sedangkan hukum positif yang diberlakukan di pemerintahan masih memerlukan sosialisasi secara pelan-pelan ( contoh masyarakat baru sadar betapa penting identitas hukum, betapa penting akta nikah,akta kelahiran dan lain lain) mereka akan berusaha keras mencari akta-akta tersebut pada saat sudah mendesak untuk pergunakan seperti akan menunaikan ibadah haji pembuatan paspor ternyata memerlukan akta nikah, untuk anak sekolah memerlukan akte kelahiran .
Kelemahan selama ini apa bila ditanya kepada pelaku perkawinan atau poligami sirri yang tidak dicatatkan adalah karena hal itu bukan aib yang melanggar nurma. Akibatnya perlindungan hukum kepada istri dan anak hasil poligami sirri menjadi lemah.

Kepada pemerintah daerah dan jajaran terkait berupaya memberi penyuluhan hukum sekaligus pembelajaran agar masyarakat memahami pentingnya perlindungan hukum dalam keluarga, sehingga perempuan-perempuan dan anak-anak memperoleh perlindungan hukum secara nyata, agar meperoleh hak-haknya layaknya perempuan dan anak-anak dari perkawinan normal

Direkomendasikan/ disarankan kepada DPR bersama Pemerintah agar merevisi pasal 4 UU No 1 tahun 1974 tentang perkawinan ditambah satu ayat, pasal 5 ayat (2) UU No 1 tahun 1974 tentang perkawinan di tambah kalimat agar lebih jelas dan terinci serta Pemerintah merevisi pasal 7 ayat (3) KHI demi kepastian hukum dan perlindungan hukum di tambah satu huruf $f$,demi memenuhi prinsip jaminan dasar ( ushul al-khamsah).

Tuntutan perlindungan hukum kepada semua warga negara demi tegaknya prinsip jaminan perlindungan hidup (usul al khamsah) memerlukan peran hakim, dengan membuat pergeseran hukum melalui teori maslahah , ketentuan nurmatif yang asalnya tidak dapat menjadi dapat, maka prosedur pengesahan poligami sirri sepanjang tidak bertentangan dengan syariat hukum Islam itsbat kontentius (itsbat poligami sirri) dapat di lakukan sebagai jalan keluarnya. Dengan dapat diitsbatkan poligami sirri yang tidak terhalang oleh hukum Islam tersebut secara praktik dapat memberikan pedoman bagi praktisi hukum dan stake holder di bidang hukum bahwa dengan cara itu dapat memberikan jaminan perlindungan hukum bagi Istri dan anak hasil poligami sirri. 


\section{Daftar Pustaka}

Abdul Manan , 2006, Aspek-Aspek Pengubah Hukum, Kencana Prenada Media,Jakarta,cetakan ke 3.

Abdul Manan. Penerapan hukum Acara Perdata di lingkungan Peradilan Agama. Yayasan Al-hikmah.Jakarta. cetakan pertama.

Adriaan Bedner, 2011, di buku "Seri tokoh hukum indonesia satjipto rahardjo dan hukum progresif urgensi dan kritik" ,Epistima Institute,Jakarta.

Agus Salim (ed) ,2001, Teori dan Paradigma Penelitian Sosial (dari Denzim Guba\& Penerapanya), Tiara Wacana Yogyakarta.

Barder Johan Nasution,2008, Metode Penelitian Ilmu Hukum, Mandar Maju,Bandung.

Bahder Johan Nasution,2014,Negara Hukium dan Hak Asasi Manusia,CV.Mandar Maju,Bandung,cetakan ke-III.

George Whitecross Paton, A Text Book Of jurisprudence, Second Edition, Oxford At The Clarendon Press.

H.Abd.Rahman Ghazaly,2006,Fiqih Munakahat seri Buku Daras, Kencana, Jakarta,Cetakan kedua.

H.Abdul Manan,2007,Reformasi Hukum Islam Di Indonesia Tinjauan dari Aspek Metodologi. Legalisasi ,dan Yurisprudensi,Raja Grafindo Persada, Jakarta.

H.Abdul Manan, 2006, Aspek-Aspek Pengubah Hukum, Kencana,Jakarta,Cetakanke-3.

Ibnu Rusyd,2011,Bidayatul Mujtahid,terjemah Abu Usamah Fakhtur, jilid 2, Pustaka Azzam,Jakarta,cetakan kedua.

Insklopedia Pengetahuan Al-qur'an dan Hadits, Jilid 6,2014,cetakan kedua,Kamil Pustaka,Jogjakarta.

Imam Jalaluddin Abdurahman AI Syuyuthi, 1983, Al-Ashbah wa al annadlair, daaru al kutub al 'alamiyah, Beirut.

Imam Abi Husein Muslim Ibn Hijaz, Soheh Muslim,Daarul Fikr.

Imam Syafi'l, 2006, Muhtashar AI Umm Fii Al-Fiqh,terjemah Abu Vida'Anshari dkk, Jilid 5, Menara Kudus.

Jerome Frank, 2014,Hukum \& Pemikiran Modern,alih bahasa oleh Rahmani Astuti dari buku Law and The Modern Mind,cetakan II , Nuansa Cendekia,Bandung.

Jurnal Hukum dan Peradilan volume 1 nomor 3 November 2012, Mahkamah Agung RI Badan Penelitian dan Pengembangan Hukum dan Peradilan.

Jurnal Hukum dan Peradilan volume 02 nomor 1 Maret 2013. Mahkamah Agung RI Badan Penelitian dan Pengembangan Hukum dan Peradilan.

Kamus Besar Bahasa Indonesia,2008, edisi ke tiga,Pusat Bahasa Departemen Pendidikan Nasional,Balai Pustaka,Jakarta.

Kamus Besar Bahasa Indonesia,edisi kedua,1995, Departemen Pendidikan dan Kebudayaan,Balai Pustaka ,Jakarta.

Komisi Yudisial,Potret Profesionalisme Hakim Dalam Putusan, laporan Penelitian Putusan Pengadilan Negeri 2008. 
Mahmud Syaltut,1966 ,al- Fatawa (diraasatu limusykilati al-muslim al-mu'asyirin hayatuhu yaumiah wa al-'aamah), Daarul Qalam,cetakan ke 3.

Moh.Mahfud MD dkk,2013,Dekonstruksi dan Gerakan Pemikiran Hukum Progresif ,Thafa Media, Jogjakarta.

Moh.Mahfud MD,1999, Hukum dan Pilar-Pilar Demokrasi, Gama Media,Jogjakarta.

Varia Peradilan majalah hukum no.254 tahun ke XXII januari 2007 .

Varia peradilan majalah hukum tahun XXIV no. 285 agustus 2009 .

Werner Menski, 2014,perbandingan hukum dalamkonteks global sistem eropa,asia dan afrika,nusamedia,cetakan II.

Yahya harapap,2008, hukum acara perdata,Sinar Grafika ,Jakarta. 